\title{
Nutritional status of schoolchildren in an inner city area
}

\author{
W Doyle, S Jenkins, M A Crawford, K Puvandendran
}

\begin{abstract}
Data were collected on the seven day weighed food intakes of 65 schoolchildren, aged 12-13 years, living in an inner city, socially deprived area in east London. Blood samples were collected during the week and analysed for cholesterol, serum ferritin, vitamins $A, E, B-12, \beta$ carotene, and folic acid.

Boys generally fared better than girls with almost a quarter of the girls having intakes of calcium, magnesium, iron, zinc, vitamin $A$, and riboflavin less than the lower reference nutrient intake, an amount which, by definition, is enough for only the few people in a group who have low needs. Although the mean energy intake was close to the estimated average requirement for both boys and girls, $74 \%$ did not meet the recommended intake for fibre and a high proportion of children consumed more than $11 \%$ of their energy from saturated fat $(85 \%)$ and added sugar $(88 \%)$.

Thirty seven per cent of the children ate no fresh fruit during the week they kept a diary and only $19 \%$ had vegetables (fresh or frozen), other than potatoes, on a daily basis. Their main sources of energy were chips, bread, and confectionery.

No association was found between fat intakes and plasma cholesterol concentrations. Girls had significantly lower blood concentrations of folic acid, ferritin, and $\beta$ carotene.

The findings of this study confirm the anxieties often expressed that many schoolchildren, particularly in less affluent areas, are eating diets which are unhealthy according to government recommendations.

(Arch Dis Child 1994; 70: 376-381)
\end{abstract}

Institute of Brain Chemistry and Human Nutrition, Queen Elizabeth Hospital for Children, Hackney Road, London E2 8PS W Doyle

M A Crawford

Department of Child Health, St Leonard's Primary Care Centre, London

S Jenkins

K Puvandendran

Correspondence to: Wendy Doyle.

Accepted 26 January 1994

previous study of the nutrient intakes group of pregnant women in the inner city borough of Hackney in east London highlighted the fact that there was an important minority of women who ate a poor diet in terms of quantity and quality and that poor diet correlated with low birth weight and an unsatisfactory outcome of pregnancy. ${ }^{1-5}$ Following on from that study, we were interested in looking at a younger age group; this paper reports the results of a study of the nutritional status of schoolchildren living in the same area.

There has been considerable interest in the diet of children in relation to their optimum growth and development, their behaviour and their risk of developing degenerative diseases, particularly cardiovascular disease, in later life. ${ }^{6-8}$

Although there is much anecdotal evidence of the 'unhealthy' diets of many schoolchildren, there is little accurate data available on the dietary intakes of children living in deprived inner city areas. The Department of Health published a report in 1989 on the diets of schoolchildren in which they suggested that the diets of British schoolchildren were on the whole, satisfactory, ${ }^{9}$ despite three quarters of children having obtained more than $35 \%$ of their energy from fat; saturated fat intakes were not reported. Although the 'median' intakes of most of the reported micronutrients met the recommended intakes, the intakes of calcium, iron, riboflavin, and vitamin A (retinol equivalents) were unsatisfactory in some groups of children.

We were concerned not so much with the 'average' child but with the socially disadvantaged, high risk child - the child whom both the Office of Population Censuses and Surveys and many researchers have shown is at greatest risk of birth abnormalities and of developing heart disease, cancer, and other preventable diseases in later life. The 1988 COMA report on infant feeding, ${ }^{6}$ and the 1990 WHO report on prevention in childhood and youth of adult cardiovascular diseases, ${ }^{7}$ both endorse the need to promote health awareness and a healthy diet from an early age. Additionally, 'Health of the Nation' priorities for the prevention of coronary heart disease and stroke have focused attention on the importance of diet and lifestyle. ${ }^{10}$

Epidemiological studies by Barker $e t$ al have given credence to an association between poor maternal nutrition and health and an increased risk of diseases of the cardiovascular system to the unborn child in later life. ${ }^{11}$ Further, there is evidence to indicate a relation between nutrition, behaviour, and intellectual performance in young children and in schoolchildren. ${ }^{12-14}$

\section{Subjects and methods}

Before beginning the study, permission and ethical approval was granted by the Inner London Education Authority and by the district ethical committee. A parents' evening was arranged at the school to explain the purpose of the study and to allow parents to meet the researchers. This was followed by a letter to individual parents asking for their written consent and that of their child.

The children, aged 12-13 years, were all second year pupils at one secondary mixed school serving a deprived area in Hackney. 
Table 1 Mean energy and nutrient intake of boys and girls each day

\begin{tabular}{|c|c|c|c|c|}
\hline & \multicolumn{2}{|l|}{ Boys $(n=35)$} & \multicolumn{2}{|l|}{ Girls $(n=30)$} \\
\hline & Mean (SD) intake & $R N I^{\star}$ & Mean (SD) intake & $R N I^{\star}$ \\
\hline Energy (MJ) $\dagger$ & $9 \cdot 13(2.02)$ & $9 \cdot 27$ & $7.90(1.66)$ & $7 \cdot 72$ \\
\hline $\begin{array}{c}{[\mathrm{kcal}]} \\
\operatorname{Protein}(\mathrm{g})\end{array}$ & $\begin{array}{c}2183(484) \\
64.9(13.4)\end{array}$ & $\begin{array}{c}2220] \\
42 \cdot 1\end{array}$ & $\begin{array}{c}1889(398) \\
55(12 \cdot 1)\end{array}$ & $\begin{array}{c}1845] \\
41 \cdot 2\end{array}$ \\
\hline Fat $(\mathrm{g})$ & $88(26 \cdot 2)$ & $\begin{array}{l}42.1 \\
-\end{array}$ & $76.5(17 \cdot 1)$ & 41.2 \\
\hline Carbohydrate (g) & $301(64 \cdot 3)$ & - & $262(65.2)$ & - \\
\hline Total sugar $(\mathrm{g})$ & $135(44 \cdot 2)$ & - & $111(47)$ & - \\
\hline Added sugar (g) & $104(38 \cdot 5)$ & - & $87 \cdot 7(44 \cdot 3)$ & - \\
\hline Fibre (g) & $16 \cdot 2(4 \cdot 7)$ & 18 & $15.5(3.9)$ & 18 \\
\hline Cholesterol (g) & $200(79)$ & - & $165(94.9)$ & - \\
\hline Calcium (mg) & $719(248)$ & 1000 & $627(205)$ & 800 \\
\hline Magnesium (mg) & 239 (59) & 280 & $209(53 \cdot 1)$ & 280 \\
\hline Iron (mg) & $10.9(2 \cdot 8)$ & $11 \cdot 3$ & $9 \cdot 68(2.9)$ & $14 \cdot 8$ \\
\hline Zinc (mg) & $7 \cdot 64(2)$ & 9 & $6.62(1.6)$ & 9 \\
\hline Vitamin A $(\mu \mathrm{g})$ & $624(602)$ & 600 & $415(211)$ & 600 \\
\hline Vitamin D $(\mu \mathrm{g})$ & $3.64(3.4)$ & - & $2.9(2 \cdot 2)$ & - \\
\hline Vitamin E (mg) & $8.83(3.9)$ & - & $7.01(1.8)$ & - \\
\hline Thiamin (mg) & $1.09(0.3)$ & 0.9 & $0.95(0.3)$ & $0 \cdot 7$ \\
\hline Riboflavin (mg) & $1.29(0.5)$ & $1 \cdot 2$ & $1.08(0.4)$ & $1 \cdot 1$ \\
\hline Niacin (mg) & $15 \cdot 3(3.4)$ & 15 & $13 \cdot 5(4 \cdot 2)$ & 12 \\
\hline Pyridoxine (mg) & $1 \cdot 51(0 \cdot 4)$ & $1 \cdot 2$ & $1.32(0.5)$ & 1 \\
\hline Vitamin B-12 $(\mu \mathrm{g})$ & $3.70(3.4)$ & $1 \cdot \overline{2}$ & $3.02(2)$ & $1 \cdot 2$ \\
\hline Folic acid $(\mu \mathrm{g})$ & $167(60 \cdot 7)$ & 200 & $142(52)$ & 200 \\
\hline Vitamin C (mg) & $60 \cdot 5(26 \cdot 3)$ & 35 & $58 \cdot 4(31 \cdot 2)$ & 35 \\
\hline Fat $(\%$ en $) \dagger$ & $36 \cdot 6(4 \cdot 4)$ & 35 & $35 \cdot 7(3.4)$ & 35 \\
\hline Saturated fat (\%en) & $13 \cdot 1(2 \cdot 3)$ & 11 & $13.2(1.9)$ & 11 \\
\hline Polyunsaturated (\%en) & $6.3(1.6)$ & 6 & $6 \cdot 4(1 \cdot 6)$ & 6 \\
\hline Carbohydrate (\%en) & $51 \cdot 2(4 \cdot 3)$ & 50 & $52 \cdot 6(4 \cdot 4)$ & 50 \\
\hline Added sugar (\%en) & $16 \cdot 3(4 \cdot 7)$ & 11 & $18 \cdot 4(6)$ & 11 \\
\hline
\end{tabular}

$\star \mathrm{RNI}=$ reference nutrient intake.

t\%en $=$ Percentage of energy intake from that source.

From a total of 149 pupils, written consent was obtained from $87(58 \%)$ pupils and their parents. Sixty five (44\%) children, 35 boys and 30 girls, completed seven day weighed food intake diaries of an acceptable standard for dietary analysis; 22 diaries were incomplete. The children were provided with digital dietetic scales (Soehnle) to weigh their food, together with personal instructions on their use. They were seen each schoolday by the dietitian so that their diaries could be checked. Each week an average of 15 pupils kept diaries; the study was carried out during the spring and summer terms. The dietitian was present in the school dining room each lunchtime to help and encourage the children to fill their diaries and to check on the recipes used in the kitchen. The children were encouraged to keep all confectionery, crisp, and other wrappers of food eaten.

Blood samples $(10 \mathrm{ml})$ were collected from $66(44 \%)$ children ( 32 girls and 34 boys) by venepuncture. Those who gave blood samples

Table 2 Percentage of boys and girls with mean micronutrient intakes less than the dietary reference values

\begin{tabular}{|c|c|c|c|c|c|c|}
\hline & \multicolumn{3}{|c|}{ Boys $(n=35)$} & \multicolumn{3}{|c|}{ Girls $(n=30)$} \\
\hline & $L R N I$ & $E A R$ & $R N I$ & $L R N I$ & $E A R$ & $R N I$ \\
\hline Energy & - & 57 & - & - & 43 & - \\
\hline Calcium & 14 & 69 & 94 & 30 & 53 & 77 \\
\hline Magnesium & 14 & 40 & 86 & 27 & 67 & 90 \\
\hline Iron & 0 & 26 & 69 & 23 & 80 & 97 \\
\hline Zinc & 3 & 54 & 77 & 23 & 53 & 93 \\
\hline Vitamin A (retinol equivalent) & 11 & 34 & 57 & 23 & 60 & 80 \\
\hline Vitamin B-1 & 0 & 6 & 26 & 0 & 10 & 17 \\
\hline Vitamin B-2 & 9 & 34 & 52 & 30 & 43 & 50 \\
\hline Niacin & 3 & 20 & 43 & 3 & 20 & 40 \\
\hline Vitamin B-6 & 0 & 0 & 0 & 0 & 3 & 3 \\
\hline Vitamin B-12 & 3 & 3 & 3 & 3 & 7 & 10 \\
\hline Folic acid & 9 & 57 & 71 & 13 & 63 & 90 \\
\hline Vitamin C & 0 & 0 & 14 & 0 & 3 & 20 \\
\hline Expected & $2 \cdot 5$ & $50 \cdot 0$ & $97 \cdot 5$ & $2 \cdot 5$ & $50 \cdot 0$ & $97 \cdot 5$ \\
\hline
\end{tabular}

$\mathrm{LRNI}=$ lower reference nutrient intake; $E A R=$ estimated average intake; and $\mathrm{RNI}=$ reference nutrient intake.

${ }^{\star}$ Percentage of children with more than recommended energy intake from: (a) fat, $57 \%$ (boys), $70 \%$ (girls); (b) saturates, $80 \%$ (boys), $90 \%$ (girls); (c) added sugar, $89 \%$ (boys), $87 \%$ (girls). were not necessarily the same as those who completed successful dietary records. Forty five children overlapped, providing both diet records and blood samples. The blood samples were analysed for cholesterol, serum ferritin, vitamin $E$, vitamin $A, \beta$ carotene, folic acid, vitamin $\mathrm{B}-12$, and biotin.

Information was also collected from the children using a short questionnaire on the amount of exercise taken, smoking, and drinking habits.

\section{ANALYSIS}

The records were analysed using a computerised nutrient database, based on McCance and Widdowson, ${ }^{15}$ to which we have added our own analytical data on the fatty acid composition of foods. These data include the amount of 48 different fatty acids with isomers separated into all cis, cis-trans, trans-trans, and positional isomers. Because of the wide range of fats and oils in use, the software prompts the user to define the types of fat used by each pupil in each specific recipe or menu. This allows the different margarines, cooking fats, and oils, as well as the make of some high fat foods such as crisps, mayonnaise, and chocolate confectionery, to be specified in an individual child's record.

After the study the children were each provided with a personal report, based on the results of their week's intake, about the quality of their diet and how they could improve it.

\section{BLOOD ANALYSES}

Serum ferritin concentrations were determined at Great Ormond Street Hospital in London. The assays of vitamins and cholesterol were carried out by Hoffman-La Roche in Switzerland.

\section{Results}

\section{NUTRIENT INTAKES}

Table 1 compares individual nutrient intakes with reference nutrient intakes. ${ }^{16}$ The reference nutrient intake for protein, vitamins, and minerals is the amount of a nutrient that is enough to meet the requirements of about $97 \%$ of subjects in a group; therefore, if the average intake of the group is at or above the reference nutrient intake, the risk of deficiency is very small.

Sixty three per cent of the children obtained more than $35 \%$ of their food energy from fat; $85 \%$ obtained more than $11 \%$ from saturated fat. A higher proportion of girls than boys were outside the recommended limit for both fat and saturated fat (table 2).

Eighty eight per cent of the children had more than $11 \%$ of their food energy from added sugar (non-milk extrinsic sugar) and over a third of the children had $20 \%$ or more.

The combined proportion of food energy derived from fat and non-milk extrinsic sugar ranged from 39 to $63 \%$, with an average contribution from this energy of $54 \%$. These children were thus largely dependent on less 
Table 3 Micronutrient intake each day and significance of difference with intake of breakfast cereals

\begin{tabular}{|c|c|c|c|}
\hline & \multicolumn{2}{|c|}{ Mean intake } & \multirow[b]{2}{*}{ p Value $e^{\star}$} \\
\hline & $\begin{array}{l}\text { Breakfast } \\
\text { cereals } \\
\geqslant 4 / \text { week } \\
(n=20)\end{array}$ & $\begin{array}{l}\text { Breakfast } \\
\text { cereals } \\
\leqslant 3 / \text { week } \\
(n=45)\end{array}$ & \\
\hline $\begin{array}{r}\text { Energy (MJ) } \\
{[\mathrm{kcal}]}\end{array}$ & $\begin{array}{r}8.98 \\
{[2149]}\end{array}$ & $\begin{array}{r}8 \cdot 37 \\
{[2002]}\end{array}$ & $0 \cdot 159$ \\
\hline Fat (g) & 104 & 93.4 & 0.486 \\
\hline Added sugar (g) & 84.9 & $81 \cdot 7$ & 0.495 \\
\hline Fibre $(\mathrm{g})$ & $16 \cdot 7$ & $15 \cdot 5$ & 0.071 \\
\hline Calcium (mg) & 807 & 619 & 0.005 \\
\hline Magnesium (mg) & 257 & 211 & 0.002 \\
\hline Iron $(\mathrm{mg})$ & $12 \cdot 4$ & $9 \cdot 38$ & $<0.001$ \\
\hline Zinc (mg) & $7 \cdot 99$ & $6 \cdot 81$ & 0.005 \\
\hline Phosphorus (mg) & 1142 & 940 & 0.002 \\
\hline Vitamin D $(\mu \mathrm{g})$ & $4 \cdot 77$ & $2 \cdot 65$ & 0.017 \\
\hline Thiamin (mg) & $1 \cdot 24$ & 0.93 & $<0.001$ \\
\hline Riboflavin (mg) & 1.68 & 0.98 & $<0.001$ \\
\hline Niacin (mg) & $17 \cdot 1$ & $13 \cdot 3$ & $<0.001$ \\
\hline Pyridoxine (mg) & 1.75 & $1 \cdot 27$ & $<0.001$ \\
\hline Vitamin B-12 ( $\mu \mathrm{g})$ & 4.97 & $2 \cdot 68$ & 0.001 \\
\hline Folic acid $(\mu \mathrm{g})$ & 200 & 136 & $<0.001$ \\
\hline Pantothenic acid (mg) & $3 \cdot 27$ & $2 \cdot 66$ & 0.003 \\
\hline Biotin (mg) & 16.9 & $13 \cdot 0$ & 0.016 \\
\hline
\end{tabular}

^Mann-Whitney U test (two tailed).

than half their energy intake to supply almost all the essential micronutrients.

About a quarter of the girls had less than the lower reference nutrient intake (LRNI) for calcium, magnesium, iron, zinc, and riboflavin; $13 \%$ had a folic acid intake less than the LRNI (table 2). More boys than expected also had intakes less than the LRNI for calcium, magnesium, vitamin A, riboflavin, and folic acid. This was reflected in the nutrient density of their diets in that the boys tended to choose foods with a higher vitamin and mineral content per 1000 kilocalories.

There was no significant difference between any nutrient intake of those who were entitled to free school meals (42\%) and those who were not $(58 \%)$.

\section{FOOD PATTERNS}

There was a striking lack of variety of foods eaten by this group of children, with a low consumption of fruit and vegetables. Forty per

Table 4 Mean (SD) blood concentrations of selected nutrients and significant differences (Mann-Whitney $U$ test, two tailed)

\begin{tabular}{|c|c|c|c|}
\hline Plasma concentration & Girls $(n=32)$ & Boys $(n=34)$ & p Value \\
\hline $\begin{array}{l}\text { Ferritin }(\mu \mathrm{g} / \mathrm{l}) \\
\text { Vitamin E }(\mu \mathrm{mol} / 1) \\
\text { Vitamin } A(\mu \mathrm{mol} / 1) \\
\beta \text { Carotene }(\mu \mathrm{mol} / 1) \\
\text { Folic acid }(\mathrm{nmol} / \mathrm{l}) \\
\text { Vitamin B-12 }(\mathrm{pmol} / \mathrm{l}) \\
\text { Cholesterol }(\mathrm{mmo} / /)\end{array}$ & $\begin{array}{c}19 \cdot 8(15 \cdot 9)[\mathrm{n}=25] \\
16 \cdot 3(2 \cdot 92) \\
1 \cdot 24(0 \cdot 27) \\
0 \cdot 47(0 \cdot 26) \\
14 \cdot 0(5 \cdot 15) \\
478(174) \\
3.79(0 \cdot 56)\end{array}$ & $\begin{array}{c}27 \cdot 1(17 \cdot 7)[n=24] \\
15 \cdot 5(3 \cdot 98) \\
1 \cdot 20(0 \cdot 21) \\
0 \cdot 60(0 \cdot 31) \\
18 \cdot 1(6 \cdot 90) \\
481(210) \\
3 \cdot 76(0 \cdot 73)\end{array}$ & $\begin{array}{l}0.037 \\
\text { NS } \\
\text { NS } \\
0 \cdot 047 \\
0.020 \\
\text { NS } \\
\text { NS }\end{array}$ \\
\hline
\end{tabular}

Table 5 Percentage of 66 children at risk of deficiency for five key nutrients (based on risk level defined for adult population)

\begin{tabular}{|c|c|c|c|c|}
\hline Serum & $\begin{array}{l}\text { High risk: } \\
\text { 'deficient' }\end{array}$ & $\begin{array}{l}\text { Moderate risk: } \\
\text { 'marginal' }\end{array}$ & $\begin{array}{l}\text { Low risk: } \\
\text { 'adequate' }\end{array}$ & $\begin{array}{l}\text { Very low risk: } \\
\text { 'optimal' }\end{array}$ \\
\hline $\begin{array}{l}\text { Vitamin } \mathrm{E}(\mu \mathrm{mol} / \mathrm{l}) \\
\% \text { Of children }\end{array}$ & $\begin{array}{r}<15 \\
38\end{array}$ & $\begin{array}{l}15-20 \\
52\end{array}$ & $\begin{array}{r}>20 \\
8\end{array}$ & $\begin{array}{r}>25 \\
2\end{array}$ \\
\hline $\begin{array}{l}\text { Vitamin A ( } \mu \mathrm{mol} / \mathrm{l}) \\
\% \text { Of children }\end{array}$ & $\begin{array}{l}<1 \cdot 00 \\
17\end{array}$ & $6^{1 \cdot 00-1 \cdot 40}$ & $\begin{array}{l}>1 \cdot 40 \\
15\end{array}$ & $\begin{array}{l}2 \cdot 00-4 \cdot 00 \\
0\end{array}$ \\
\hline $\begin{array}{l}\beta \text { Carotene }(\mu \mathrm{mol} / \mathrm{l}) \\
\% \text { Of children }\end{array}$ & $\begin{array}{l}<0 \cdot 30 \\
24\end{array}$ & $5^{0 \cdot 30-0 \cdot 70}$ & $\begin{array}{l}>0 \cdot 70 \\
15\end{array}$ & $\begin{array}{c}>1 \cdot 20 \\
6\end{array}$ \\
\hline $\begin{array}{l}\text { Folic acid }(\mathrm{nmol} / \mathrm{l}) \\
\% \text { Of children }\end{array}$ & $\begin{array}{r}<7 \\
0\end{array}$ & $41^{7-12}$ & $\begin{array}{r}>12 \\
26\end{array}$ & $\begin{array}{r}>18 \\
32\end{array}$ \\
\hline $\begin{array}{l}\text { Vitamin B-12 (pmol/1) } \\
\% \text { Of children }\end{array}$ & $\begin{array}{r}<150 \\
0\end{array}$ & $\begin{array}{l}150-220 \\
3\end{array}$ & $\begin{array}{r}>220 \\
26\end{array}$ & $\begin{array}{r}>350 \\
71\end{array}$ \\
\hline
\end{tabular}

cent of girls and $34 \%$ of boys ate no fresh fruit during the week they kept a diary. Few children (17\% of girls and $20 \%$ of boys) ate a portion of fresh or frozen vegetables, other than potatoes, on a daily basis.

A third of the children ate nothing before starting school in the mornings. Although most $(66 \%)$ did eat something, it was often a low nutrient density food such as confectionery or crisps. Only $20 \%$ ate breakfast cereals on a regular basis and this was reflected in their significantly higher micronutrient intakes (table 3).

A comparison of those who ate breakfast cereals four or more times each week with those who ate cereals three or less times each week revealed a significant difference in their intakes of most micronutrients (table 3), but not in energy intake.

The children also had a high consumption of chips, crisps, sweetened fizzy drinks, and all sorts of confectionery. The average number of portions of chips eaten was three each week by boys and 3.6 by girls. Girls ate twice as many bags of crisps ( 5.8 each week) as boys ( 2.6 each week).

\section{BLOOD RESULTS}

\section{Range of values}

We were unable to find generally accepted normal paediatric ranges for blood nutrient concentrations except for serum ferritin. Guidelines for vitamin status in adults were provided by Hoffman-La Roche and aim to define ranges for high, moderate, low, and very low risk of clinical deficiency; paediatric guidelines are not available. We have used, with reservations as stated, the guidelines for vitamin status in adults for comparative purposes.

The means and percentages of children at risk of clinical vitamin deficiency according to the Hoffman-La Roche guidelines for adults can be seen in tables 4 and 5; serum ferritin and cholesterol concentrations are given in table 6 .

\section{Vitamin A}

Seventeen per cent of those assayed were at high risk of clinical deficiency. A slightly higher proportion of boys than girls (88 $v 81 \%$ ) fell into this category.

\section{$\beta$ Carotene}

Twenty one per cent of boys and $44 \%$ of girls had $\beta$ carotene concentrations less than the lower limit of $0.30 \mu \mathrm{mol} / 1$.

\section{Vitamin $E$}

Thirty eight per cent of the children were at high risk of clinical deficiency of vitamin $\mathrm{E}$.

Folic acid

None of the children was below the lower limit of $7.0 \mathrm{nmol} / 1$. Surprisingly, $35 \%$ of the boys and $12 \%$ of the girls had concentrations higher 
Table 6 Serum ferritin and cholesterol concentrations (number of children)

\begin{tabular}{|c|c|c|c|c|c|c|c|}
\hline & \multicolumn{3}{|c|}{ Ferritin $(\mu g /)^{\star}$} & \multicolumn{4}{|c|}{ Cholesterol (mmoll) } \\
\hline & $<10$ & $\leqslant 15$ & $\leqslant 20$ & $<4 \cdot 0$ & $4 \cdot 0-4 \cdot 5$ & $4 \cdot 5-5 \cdot 0$ & $>5.0$ \\
\hline $\begin{array}{l}\text { Girls }(n=25) \\
\text { Boys }(n=24) \\
\text { Girls and boys }(n=66)\end{array}$ & $\begin{array}{l}7 \\
2\end{array}$ & $\begin{array}{r}13 \\
5\end{array}$ & $\begin{array}{r}16 \\
8\end{array}$ & 43 & 13 & 7 & 3 \\
\hline
\end{tabular}

${ }^{\star}$ Normal range $=10-200 \mu \mathrm{g} /$.

than the top of the normal range $(45.3 \mathrm{nmol} / \mathrm{l})$. This was to some extent reflected in the higher proportion of boys whose intake of folic acid was above the reference nutrient intake $(30 \%)$ than girls $(10 \%)$. The coefficient of correlation (Pearson's between folic acid intake and blood concentration was $0 \cdot 44$.

\section{Vitamin B-12}

No child was at high risk of a clinical deficiency of vitamin B-12. Pearson's coefficient of correlation between vitamin B-12 intake and blood concentration was $0 \cdot 285$.

\section{Serum ferritin}

Iron depletion is thought to correspond with a serum ferritin concentration less than $10 \mu \mathrm{g} / \mathrm{l}$. On that basis $28 \%$ of girls and $8 \%$ of boys had low iron stores (table 6). A high proportion ( $64 \%$ of girls and $33 \%$ of boys) was at the lower end of the range $(10-200 \mu \mathrm{g} / 1)$, however, with less than $20 \mu \mathrm{g} /$.

\section{Cholesterol}

The normal blood cholesterol range for children is 3.5-5.4 mmol/l (Hoffman-La Roche). Cholesterol concentrations were generally low with a mean of $3.78 \mathrm{mmol} / 1$ and no difference between the girls and boys (table 6). Interestingly, $47 \%$ of boys and $34 \%$ of girls had concentrations less than the lower limit. Only one boy was above the upper limit at $5 \cdot 8$ $\mathrm{mmol} / \mathrm{l}$.
There was no association between intakes of fat, saturated fat, or fibre and plasma cholesterol concentrations in this population of children.

\section{Discussion}

Most children in this study were eating diets which were unhealthy according to all the recent recommendations based on the dietary reference values of key nutrients. Eighty five per cent of children were obtaining more than $11 \%$ of their energy from saturated fat, the target set in the Committee on Medical Aspects of Food Policy with the aim of reducing morbidity and mortality from heart disease and stroke. ${ }^{16}$ Interestingly, however, plasma cholesterol concentrations in the sample were low, with only one child above the upper limit of the range; also, no association was found between fat intake and plasma cholesterol concentrations. This is in contrast with adult studies ${ }^{1718}$ and with a recent study of over 1000 children from Northern Ireland where fat intakes were found to be high and $11-24 \%$ of the sample exceeded the acceptable limits for serum lipid concentrations. ${ }^{8}$ It does, however, suggest that intervention to alter dietary habits in the early teens may have potential for the prevention of coronary disease.

The average intake of added sugars, which approximates to the Department of Health's 'non-milk extrinsic' sugar classification, accounted for $17 \%$ of their total energy intake. This figure is similar to that of children in Northumberland reported by Rugg-Gunn et $a l,{ }^{19}$ a figure which they point out is considerably higher than the $0-11 \%$ of total energy intake recommended by the Department of Health (1991) for groups not consuming alcohol.

The definition of LRNIs for protein, vitamins, and minerals is that amount that is enough for only a few people in a group who have low needs. If individuals habitually eat less than the LRNI, they will almost certainly

Table 7 Mean energy sources (intake of food/day) by food groups in order of energy intake/day in boys

\begin{tabular}{|c|c|c|c|c|}
\hline \multirow{2}{*}{ Food group } & \multicolumn{2}{|l|}{ Boys } & \multicolumn{2}{|l|}{ Girls } \\
\hline & Mean MF (kcal)/day & $\%$ Energy/day & Mean MF (kcal)/day & $\%$ Energy/day \\
\hline Chips & $1 \cdot 15(276)$ & $12 \cdot 8$ & $0.96(230)$ & $12 \cdot 2$ \\
\hline Bread, white & $0.89(212)$ & $9 \cdot 8$ & $0.94(226)$ & $12 \cdot 0$ \\
\hline Confectionery & $0.86(206)$ & $9 \cdot 6$ & $0.63(150)$ & $8 \cdot 0$ \\
\hline Meat & $0.71(169)$ & $7 \cdot 8$ & $0.59(141)$ & $7 \cdot 5$ \\
\hline Biscuits, cakes, and buns & $0.70(167)$ & $7 \cdot 7$ & $0.59(141)$ & $7 \cdot 5$ \\
\hline Soft drinks & $0.65(156)$ & $7 \cdot 2$ & $0.53(126)$ & $6 \cdot 7$ \\
\hline Meat products & 0.50 (119) & $5 \cdot \overline{5}$ & $0 \cdot 49(118)$ & $6 \cdot 3$ \\
\hline Milk, whole & $0.43(104)$ & $4 \cdot 8$ & $0.33(79)$ & $4 \cdot 2$ \\
\hline Rice and pasta & $0.38(90)$ & $4 \cdot 2$ & $0 \cdot 22(53)$ & $2 \cdot 8$ \\
\hline Breakfast cereals & $0.31(75)$ & $3 \cdot 5$ & $0 \cdot 25(61)$ & $3 \cdot 2$ \\
\hline Puddings and ice cream & $0.30(72)$ & $3 \cdot 3$ & $0 \cdot 16(39)$ & $2 \cdot 1$ \\
\hline Butter, margarine, low fat spreads, and oil & $0 \cdot 28(66)$ & $3 \cdot 1$ & $0.32(76)$ & $4 \cdot 0$ \\
\hline Miscellaneous & $0 \cdot 25(61)$ & $2 \cdot 8$ & $0 \cdot 26(62)$ & $3 \cdot 3$ \\
\hline Potatoes, excluding chips and crisps & $0.25(61)$ & $2 \cdot 8$ & $0 \cdot 16(38)$ & $2 \cdot 0$ \\
\hline Crisps & $0.24(58)$ & $2 \cdot 7$ & $0.51(122)$ & $6 \cdot 5$ \\
\hline Cheese and cheese dishes & $0 \cdot 24(58)$ & $2 \cdot 7$ & $0.28(67)$ & $3 \cdot 6$ \\
\hline Sugar and preserves & $0.22(53)$ & $2 \cdot 5$ & $0 \cdot 14(33)$ & $1 \cdot 8$ \\
\hline Fish and fish products & $0 \cdot 20(48)$ & $2 \cdot 2$ & $0 \cdot 11(27)$ & $1 \cdot 4$ \\
\hline Fruit, fresh fruit and fruit juice & $0.13(32)$ & 1.5 & $0.07(17)$ & 0.9 \\
\hline Bread, brown and wholemeal & $0 \cdot 11(27)$ & $1 \cdot 2$ & $0.05(13)$ & 0.7 \\
\hline Eggs and egg dishes & $0.09(21)$ & $1 \cdot 0$ & $0.07(16)$ & $0 \cdot 8$ \\
\hline Pulses & $0.06(15)$ & 0.7 & $0.07(16)$ & $0 \cdot 8$ \\
\hline Yoghurt & 0.05 (11) & 0.5 & $0.04(9)$ & 0.5 \\
\hline Leafy green vegetables and salads & $0.04(9)$ & 0.4 & $0.03(7)$ & $0 \cdot 4$ \\
\hline Nuts and seeds & $0.03(7)$ & 0.3 & $0.01(2)$ & $0 \cdot 1$ \\
\hline Milk, semiskimmed & $0.02(5)$ & $0 \cdot 2$ & $0.03(7)$ & $0 \cdot 4$ \\
\hline Fruit, tinned, stewed, and dried & $0.02(4)$ & 0.2 & $0.05(13)$ & 0.7 \\
\hline
\end{tabular}


be deficient. The relatively high proportion, particularly of girls, who had intakes below the LRNI is disturbing.

Twenty three per cent of the girls had an iron intake less than the LRNI. Based on serum ferritin concentrations, $28 \%$ of the girls had low iron stores. There was a low correlation coefficient $(0 \cdot 18)$ between iron intake and serum ferritin concentrations in this population, however. The serum ferritin concentrations of the group as a whole compare favourably with results from a study in Eire, where $40 \%$ of a group of adolescents were found to have less than $10 \mu \mathrm{g} / \mathrm{l}^{20}$ and with a study on children admitted to hospital in Bradford where $32.8 \%$ had concentrations less than $10 \mu \mathrm{g} / \mathrm{l}^{21}$ Southon et al found low concentrations in $21 \%$ of girls and $11 \%$ of boys in their Norwich based study of 13-14 year olds whose parents were assigned to social classes I-III. ${ }^{22}$ The significance of low iron stores in this age group has not been adequately explored; in younger age groups it has been found to be highly correlated with impaired growth, health, and development, which improves significantly with iron supplementation. ${ }^{14}$ There is some evidence that iron supplements in adolescents can have an effect on academic performance. ${ }^{23}$ Unless their diets improve during or after leaving school, the girls are likely to be entering pregnancy with suboptimum nutrition, and in this context the low intakes of folic acid are of particular concern in relation to the known association between low folate intakes and the incidence of neural tube defects. $^{24}$

The most important sources of energy for boys and girls were chips, bread, and confectionery, in that order (table 7). The three major sources in the diets of British schoolchildren are bread (9-11\%), chips (11\%), and milk $(6-8 \%){ }^{9}$

A third of children in this sample ate no breakfast in the morning before coming to school, and of those who did eat something it was rarely a healthy breakfast. The $20 \%$ who ate breakfast cereals on a regular basis had significantly higher micronutrient intakes. This supports the views of others that the omission of breakfast or an inadequate breakfast may particularly contribute to dietary inadequacies. ${ }^{25-27}$

The children in this study were attending an inner city school in Hackney, a district which rates highly on all indicators of deprivation. Local data from the 1981 and 1991 census show high rates of unemployment $(22 \%$ male unemployment in 1991), poor housing and overcrowding, and low rates of car ownership (62\% households had no car in 1991). ${ }^{28} \mathrm{We}$ did not specifically ask about income, but information from the school was that most families whose children took part in this study have a low income. For them the cost of an adequate diet would be a substantial proportion of their income, as highlighted in a recent poverty and nutrition survey. ${ }^{29}$ That survey, of 354 families with a low income, found that two thirds of children and over half their parents were eating nutritionally poor diets, with a direct correlation between poor diet and food expenditure.

The findings of this study confirm the anxieties often expressed that many schoolchildren, particularly in less affluent areas, are eating poor diets, and provides baseline data for intervention. In preschool children it has been shown to be possible to prevent iron deficiency by active dietary education for parents in a primary care setting. ${ }^{30} 31$ There is a clear need for specific health education campaigns at school in which school health services have the potential to play a major part. A recent MORI poll survey of 2000 Hackney secondary schoolchildren found that only just over half remembered having some lessons on nutrition at school, and there was considerable variation between schools. There was, however, considerable interest expressed by both boys and girls in having information about healthy foods, and about heart disease, with the peak interest expressed between the ages of 13 and 14 years. ${ }^{32}$ It seems logical to target the younger children and to begin health education in primary schools, focusing on exercise and smoking as well as diet and nutrition.

Counselling and education about diet can only have a limited effect unless it goes hand in hand with policies at the national and local levels which ensure that advice to individuals and families is easy to follow. In relation to diet, there is a clear need for a national food policy, adequate child benefits paid to mothers or the main carers, and the availability of cheap, nutritious school meals. ${ }^{33}$ As Macfarlane pointed out in a recent editorial, ${ }^{34}$ without such a framework teachers and health professionals should not shoulder the responsibility for initiating change.

We are grateful to the teaching and administrative staff of Hackney Free and Parochial School for their help and cooperation and also to the many schoolchildren who participated. We also express our appreciation to Steve Hurley, Hospital for Sick Children, Great Ormond Street and Dr R Salkeld, Hoffman-La Roche, Basle for analytical assistance, Dr A Johnson, Queen Elizabeth Hospital for Children and Dr L Harbige, Institute of Brain Chemistry and Human Nutrition, for help and advice. Brain Chemistry and Human Nutrition, for help and advice.
We thank Vlaardingen Research Unilever and Nutricia for We thank Vlaardingen
financial contributions.

1 Doyle W, Crawford MA, Laurance BM. Dietary survey during pregnancy in a low socio-economic group. fournal of Human Nutrition 1982; 36A: 95-106.

2 Crawford MA, Doyle W, Craft IL, Laurance BM. A comparison of food intakes during pregnancy and birthweight in high and low socio-economic groups. Prog Lipid Res 1986; 25: 249-54.

3 Doyle W, Crawford MA, Wynn AHA, Wynn SW. Maternal nutrient intake and birthweight. Fournal of Human nutrient intake and birthweight.

4 Doyle W, Crawford MA, Wynn AHA, Wynn SW. The association between maternal diet and birth dimensions. association between maternal diet and birth

5 Wynn AHA, Crawford MA, Doyle W, Wynn SW. Nutrition of women in anticipation of pregnancy. Nutr Health 1991 7: 69-88.

6 Present day practise in infant feeding: third report. London: HMSO, 1988. (Report on health and social subjects No 32.)

7 World Health Organisation. Prevention in childhood and youth of adult cardiovascular diseases: time for action. Geneva: WHO, 1990. World Health Organisation technical report series 792.)

8 Boreham C, Savage JM, Primrose D, Cran G, Strain J. Coronary risk factors in schoolchildren. Arch Dis Child 1993; 68: 182-6.

9 Department of Health. The diets of British schoolchildren. London: HMSO, 1989. (Report on health and social subjects No 36.)

10 Department of Health. The health of the nation: a consultative document for health in England. London: HMSO, 1991. (Cmnd 1523.) 
11 Barker DJP, Gluckman PD, Godfrey KM, Harding JE, Owens JA, Robinson JS. Fetal nutrition and cardiovascular disease in adult life. Lancet 1993; 341: 938-41.

12 Benton D, Roberts G. Effect of vitamin and mineral supplementation on intelligence of a sample of schoolchildren. Lancet 1988; i: $140-3$.

13 Schoenthaler SJ, Dorez WE, Wakefield JA. The impact of a low additive and sucrose diet on academic performance in 803 New York Public schools. International fournal of Biosocial Research 1986; 8: 138-48.

14 Aukett MA, Parks YA, Scott PH, Wharton BA. Treatment with iron increases weight gain and psychomotor development. Arch Dis Child 1986; 61: 849-57.

15 Paul AA, Southgate DAT. McCance and Widdowson's the composition of foods. 4th Ed. London: HMSO, 1978.

16 Dietary reference values for food energy and nutrients for the United Kingdom. London: HMSO, 1991. (Report on United Kingdom. London: HMSO

17 Keys A. Seven countries: multivariate analysis of death and coronary heart disease. Cambridge: Harvard University Press, 1980.

18 Shaper AG. Coronary heart disease: risks and reasons. Current Medical Literature, 1988

19 Rugg-Gunn AJ, Adamson AJ, Appleton DR, Butler TJ, Hackett AF. Sugars consumption by 379 11-12-year-old English children in 1990 compared with results in 1980. fournal of Human Nutrition and Dietetics 1993; 6: 419-31.

20 Armstrong PL. Iron deficiency in adolescents. BMF 1989; 298: 499 .

21 Ehrhardt $\dot{P}$. Iron deficiency in young Bradford children from different ethnic groups. $B M \mathcal{M}$ 1986; 292: 90-3.

22 Southon S, Bailey AL, Wright AJA, Belsten J, Finglas PM. Micronutrient undernutrition in British schoolchildren. Proc Nutr Soc 1993; 52: 155-63.
23 Soemantri AG, Pollitt E, Kim I. Iron deficiency anaemia and educational achievement. Am $\mathcal{F}$ Clin Nutr 1985; 42: $1221-8$.

24 Wald N, Sneddon J, Densem J, Frost C, Stone R. Prevention of neural tube defects: results of the Medical Research Council vitamin study. Lancet 1991; 338: 131-7.

25 Christakis G. A nutritional epidemiological investigation of 642 New York children. Am $\mathcal{f}$ Clin Nutr 1968; 21 : 107-26.

26 Ohlson MA, Hart BP. Influence of breakfast on total day's food intake. 7 Am Diet Assoc 1965; 47: 282-6.

27 Morgan KJ, Zabik ME, Leveille GA. The role of breakfast in nutrient intake 5- to 12-year-old children. $\mathrm{Am} \mathcal{f} \mathrm{Clin}$ Nutr 1981; 34: 1418-27.

28 Health in Hackney; annual report, 1991. London: Department of Public Health, City and Hackney Health Authority, 1991 .

29 National Children's Homes. NCH poverty and nutrition survey 1991. London: NCH, 1991

30 James J, Lawson P, Male P, Oakhill A. Preventing iron deficiency in pre-school children by implementing an educational and screening programme in an inner city practice. BMF 1989; 299: 838-40.

31 James J, Brown J, Douglas M, Cox J, Stocker S. Improving the diet of under fives in a deprived inner city practice. Health Trends 1992; 24: 161-4.

32 Health in Hackney; annual report 1992. London: Department of Public Health, City and Hackney Health Authority, 1992.

33 Report of an expert working group. Nutritional guidelines for school meals. London: The Caroline Walker Trust, 1992

34 Macfarlane A. Health promotion and children and teenagers. $B M \mathcal{Y}$ 1993; 306: 81 .

\section{Melatonin}

There seems to be a renewal of interest in the pineal gland and its hormone, melatonin. A review in the fournal of Pediatrics (1994; 123: 843-51) summarises recent work on the role of melatonin in human physiology. In seasonally breeding animals melatonin secretion is concerned in reproductive activity but human studies have failed to assign it a definite place in reproductive endocrinology. It does, though, seem to be involved in the establishment of day-night rhythms. Some blind people have sleep problems because they do not establish a normal rhythm and treatment with melatonin has improved their sleep patterns. It also improves symptoms of jet lag in normal people. A report in Developmental Medicine and Child Neurology (1994; 36: 97-107) concerns 15 children with severe neurodevelopmental disability, nine of whom were blind. All had sleep disturbance which had failed to respond to conventional management and which was causing severe family disruption. All of the families reported benefit when the children were given oral melatonin. There are no known adverse effects of such treatment. 